\title{
Surgical correction of distal tibia posttraumatic deflection
}

\author{
I. I. Trufanov, Ye. A. Pobiel, V. V. Kosylo
}

State Institution "Zaporizhzhia Medical Academy of Post-Graduate Education Ministry of Health of Ukraine"

Key words: pilon fractures, tibia, arthrosis.

Zaporozhye medical journal 2018; 20 (5), 668-673 DOI:

10.14739/2310-1210 2018.5.141655

E-mail:

trufanovivan367@ gmail.com
Objective - to study the issues related to diagnostics and treatment of pilon fracture of the tibial epiphysis and individual approach to surgical correction of posttraumatic deformations of the distal tibia.

Material and methods. The treatment results of 49 patients who had suffered pilon fractures throughout $1-2$ years after treatment completion were studied in the clinic of Traumatology and Orthopedic on the basis of "ZSMKH № 9". According to the AO classification patients had the following types of fractures: $43 \mathrm{~A}-7$ patients, $43 \mathrm{~B}-14$ and $43 \mathrm{C}-28$. The X-ray measurements characterizing the geometric shape of articular surfaces were measured. The mathematical finite element method of computer modeling was used for the study of bone and cartilaginous tissues stress distribution pattern in the ankle joint in its normal condition and in case of post-traumatic deflections.

Results. The basic pathological symptom in patients with pilon fractures of distal tibia is joint function limitation, which spreads to the sector of dorsal extension, regardless of the pilon fracture type. The joint continues to function, however movement amplitude is decreased. The most unfavorable change of distal tibia shape is valgus inclination of articular surface. This configuration change of tibial articular end requires repeated surgical correction.

Conclusions. The main task of the distal tibial epiphysis surgical correction is the weight-bearing function and axial relationships restoration and pain management. It can be concluded that selective approach to posttraumatic deformations of the distal tibia surgical correction is essential. The main indications for surgical correction are pseudarthrosis, deviations in the frontal plane of more than 10 degrees, severe joint arthrosis accompanied by pain syndrome for more than a year.
Киючові слова: перелом пілон, Аистальний віАділ великогомілково кістки, посттравматична Аеформація, псевлоартроз.

Запорізький медичний журнал. - 2018. T. 20, № 5(110). C. $668-673$

\section{Хірургічна корекція посттравматичних деформацій дистального суглобового кінця великогомілкової кістки}

\section{І. І. Труфанов, Є. А. Побєл, В. В. Косило}

Мета роботи - вивчити питання діагностики, лікування залишкових деформацій суглобового кінця великогомілкової кістки та диференційованого підходу до вибору методу оперативного лікування посттравматичних десрормацій дистального відділу гомілки.

Матеріали та методи. У клініці травматології та ортопедії на базі КУ «ЗМБКЛ № 9» вивчили результати лікування 49 хворих, які перенесли перелом pilon, в терміни від 1 до 2 років після закінчення лікування. Деформації систематизували за ознаками порушення співвісного обертання суглобових поверхонь. Здійснили кінцево-елементне моделювання напружено-деформованого стану суглобового кінця великогомілкової та малогомілкової кістки у віддаленому періоді після травми. За класифрікацією АО хворі мали такі типи переломів: 43А - 7 пацієнтів, 43В - 14, 43С - 28. Вимірювали рентгенометричні показники, що характеризують геометричну форму суглобових поверхонь. Для дослідження характеру розподілу напруження кісткової та хрящової тканин у ділянці гомілково-над'пяткового суглоба в нормі та при утворюваних посттравматичних десормаціях використали метод математичного кінцево-елементного комп'ютерного моделювання.

Результати. У хворих, які перенесли перелом pilon, основним патологічним симптомом є обмеження функції суглоба, що поширюється на сектор тильного розгинання, незалежно від типу перелому. Больовий синдром у хворих, які перенесли перелом pilon, з часом зменшується, у більшості у віддалені терміни відсутній, суглоб продовжує функціонувати, але зі зменшеною амплітудою рухів. Найбільш несприятливою зміною форми дистального суглобового кінця є нахил суглобової поверхні у фронтальній площині. Ця зміна конфігурації суглобового кінця великогомілкової кістки потребувала повторної хірургічної корекції, висвітлені показання до її виконання.

Висновки. Головним завданням хірургічної корекції дистального суглобового кінця великогомілкової кістки є відновлення опороздатності, осьових взаємовідношень і подолання больового синдрому. Показання до хірургічної корекції: псевдоартроз, нахил суглобової поверхні у фронтальній площині більш ніж $10^{\circ}$, деформуючий артроз гомілково-надп'яткового суглоба, що супроводжується больовим синдромом понад 1 рік.
Ключевые слова: перелом пилон, АистальнЫй отАел большеберцовой кости, посттравматическая Аеформация, псевдоартроз.

Запорожский медицинский журнал. - 2018. -

T. 20, № 5(110). C. $668-673$

\section{Хирургическая коррекция посттравматических деформаций дистального суставного} конца большеберцовой кости

\section{И. И. Труфанов, Е. А. Побел, В. В. Косило}

Цель работы - изучить вопросы диагностики, лечения остаточных деформаций суставного конца большеберцовой кости и дифференцированного подхода к выбору метода оперативного лечения посттравматических деформаций дистального отдела голени.

Материалы и методы. В клинике травматологии и ортопедии на базе КУ «ЗГМКБ № 9» изучены результаты лечения 49 больных, перенесших перелом pilon, в сроки от 1 до 2 лет после окончания лечения. Деформации систематизировали по признакам нарушения соосности вращения суставных поверхностей. Проведено конечно-элементное моделирование напряженно-деформированного состояния суставного конца большеберцовой и малоберцовой костей в отдаленном пе- 
риоде после травмы. Согласно классификации АО, больные имели такие типы переломов: 43А - 7 пациентов, 43B - 14, 43С-28. Измеряли рентгенометрические показатели, характеризующие геометрическую форму суставных поверхностей. Для исследования характера распределения напряжения костной и хрящевой тканей в области голеностопного сустава в норме и при возникающих посттравматических деформациях использован метод математического конечно-элементного компьютерного моделирования.

Результаты. У больных, перенесших перелом pilon, основным патологическим симптомом является ограничение функции сустава, которое распространяется на сектор тыльного разгибания, независимо от типа перелома. Болевой синдром у больных, перенесших перелом pilon, со временем уменьшается, у большинства в отдаленные сроки отсутствует, сустав продолжает функционировать, но с уменьшенной амплитудой движений. Наиболее неблагоприятным изменением формы дистального суставного конца является наклон суставной поверхности во фронтальной плоскости. Данное изменение конфигурации суставного конца большеберцовой кости требовало повторной хирургической коррекции, названы показания к ней.

Выводы. Основной задачей хирургической коррекции дистального суставного конца большеберцовой кости является восстановление опороспособности, осевых взаимоотношений и купирование болевого синдрома. Показания к хирургической коррекции: псевдоартроз, отклонение суставной поверхности во фронтальной плоскости более $10^{\circ}$, деформирующий артроз голеностопного сустава, сопровождающийся болевым синдромом более 1 года.

Fractures of the distal part of the shank are a relevant topic of modern traumatology in view of the large number of unfavorable outcomes. According to the literature, residual deflections of the tibial epiphysis account for $12-20 \%$, persistent disability up to 6-8 \% [1]. These are complex and prognostically unfavorable damages [5], requiring subsequent medical supervision by an attending doctor even after fixator removal in the long-term period [3]. According to the data of various authors, in $40 \%$ of unsatisfactory results cases repeated surgery is required. Distal tibia in the remodeling process after fracture has undergone significant changes, causing functional consequences [2]. The aim of the study is to evaluate the types of residual ankle joint incongruence after pilon fractures and the methods of their surgical correction.

\section{Objective}

To study an individual approach to surgical correction of posttraumatic deformations of the distal tibia.

\section{Material and methods}

The treatment results of 49 patients who had suffered pilon fractures throughout 1-2 years after treatment completion were studied in the clinic of Traumatology and Orthopedic on the basis of Communal Institution "Zaporizhzhia City Multidisciplinary Clinical Hospital № 9". According to the AO classification patients had the following types of fractures: $43 \mathrm{~A}-7$ patients, $43 \mathrm{~B}-14$ and $43 \mathrm{C}-28$. The methods of treatment were: closed or open reduction of fragments and their fixation with a pin and wire fixator -26 patients; open reduction of fragments and fixation with internal fixators (platinum, screws) in combination with additional external fixation - 11 patients; closed reduction of fragments using the skeletal traction system with subsequent fixation with the cylinder plaster cast - 12 patients. The X-ray measurements characterizing the geometric shape of articular surfaces were measured [2].

The mathematical finite element method of computer modeling was used for the study of bone and cartilaginous tissues stress distribution pattern in the ankle joint in its normal condition and in case of post-traumatic deflections. The model consisted of tibia and fibula bones interconnected via distal syndesmosis, bones of the foot interconnected via cartilaginous joints, the articular surface of the tibia and fibula bones and talus was covered with a $1.5 \mathrm{~mm}$ layer of cartilage (in case of deflection its thickness in appropriate places was increased). Stress was considered at the axial loading and the vertical position of the tibial axis of $800 \mathrm{~N}$ [4].

The statistical analysis of the obtained indices was carried out using IBM SPSS Statistics 20 and Microsoft Office Excel 2003. Student's t-test was used to compare the average values and identify the influence of certain factors under the condition of distribution and in case of cluster variance equality in two individual retrievals. Achieved reliability $(P)$ was calculated for all types of statistical analysis; the critical achieved reliability level for this research was 0.05 .

\section{Results and discussion}

The amplitude of ankle joint motions. Studying this clinical sign in the long-term period after the injury (a year or more after fixator removal), we have noted that almost all patients had a certain decrease in amplitude of the ankle joint motion.

The reduced joint range of motion has been noticed in all patients, its mean values were: after fractures of type $43 \mathrm{~A}$ - extension/flexion $16^{\circ} \pm 2^{\circ} / 0^{\circ} / 22^{\circ} \pm 3^{\circ}$, after fractures of type $43 \mathrm{~B}$ - extension/flexion $9^{\circ} \pm 3^{\circ} / 0^{\circ} / 19^{\circ} \pm 2^{\circ}$ and type $43 \mathrm{C}$ - extension/flexion $6^{\circ} \pm 3^{\circ} / 0^{\circ} / 20^{\circ} \pm 2^{\circ}$. Decrease in the ankle joint motion depended on the discongruence type after the pilon fracture [2] and largely extended to the segment of foot extension. In the vast majority of cases, regardless of the fracture type, extension was statistically significantly decreased in comparison with plantar flexion. In addition, it has often been noted the reduced extension function after 43B and $43 C$ fractures $(P>0.05)$.

Radiological anatomy features of ankle joint after fragments consolidation. After pilon fractures radiological anatomy of the ankle joint underwent various changes. For their systematization patients were examined using X-ray of the ankle joint, which made it possible to define the main types of the surfaces congruence abnormalities (Fig. 1).

Analyzing the above clinical and radiological manifestations, we have concluded that minor deflections of the articular surface presence in the form of "steps" up to $2 \mathrm{~mm}$, remodeling occurred due to early regenerative capacity of articular cartilage surface, as a result the sliding function was retained, though in a reduced volume. The 
residual deflections of the distal tibial articular surfaces after traction and minimally invasive treatment of pilon fractures with external fixation devices should be taken as a natural phenomenon, especially with the $43 \mathrm{C}$ fractures type.

These deflections can be systematized according to the abnormal signs in the rotational alignment of articular surfaces in the sagittal plane and on the basis of load distribution along the central and lateral (ankle) articular surfaces.

According to the literature source [2], it is seen that the most unfavorable prognostic variants are models with valgus or varus tilt of the tibial articular surface.

In the model with a valgus tilt of the tibial articular surface the stress and strain state was redistributed. The maximum value of von Mises stress in the tibial articular surface was $6.4 \mathrm{MPa}$ (the model norm is 7.6 MPa). Herewith the lateral part was influenced by a less tense than the medial part. In the central part the stress state level decreased and was equal to $3.2 \mathrm{MPa}$ (the model norm is $4.5 \mathrm{MPa}$ ).

There was an additional zone of stress concentration in the talus on the articular surface in the place of contact with the fibula. The level of stress state in it was equal to $5.3 \mathrm{MPa}$ (the model norm is $2.5 \mathrm{MPa}$ ). Thus, the greatest changes in the stressed state occurred in the fibula. The level of stress state in it become twice higher and was 6.8 $\mathrm{MPa}$ (the model norm is $2.9 \mathrm{MPa}$ ).

An increase in the stress and strain state at the apex of external ankle led to the impingement syndrome development and, as a consequence, to the compensatory formation of osteophytes. This phenomenon can be considered as a compensatory adaptive reaction aimed at increasing the joint supporting surface in response to the tibial articular site deflection.

Analyzing the results of treatment, it has been found that majority of patients, who had the termination of fixation 3-6 months ago, complained of pain, so a relatively short time. So, $83 \%$ of patients who complained of pain had had the bandage removed 3-6 months before and only 4 patients experienced pain for a longer time -1 year or more.

Some authors have reported results of the type $B$ and $\mathrm{C}$ fractures treatment using dynamic external fixation, assessing $71 \%$ subjectively and $67 \%$ objectively excellent results, despite high frequency of infections (11\%) and osteoarthritis (15\%) [8].

This fact suggests that damaged joint pain is the characteristic of early post-traumatic period and subsequently it regresses as its frequency decreases after a while. During the palpating and loading test of the ankle joint area, as a rule, painful soft tissues were localized in the corresponding zones. As a result, a relationship between the pain localization, detected by palpation, and its localization when the loading test doing has been found. This pattern manifested most frequently by the pain localization in the anterior and lateral parts of the ankle joint. For example, if during palpation of the soft tissues in the projection of the joint cleft the patient pointed to the outer surface pain, then during the loading test pain also occurred in this zone at the maximum extension foot position.

Comparing the data of clinical research and mathematical finite element method of computer modeling it can be concluded that the most unfavorable change in the distal epiphysis shape is the valgus tilt of the tibial articular surface. This change in the configuration of the tibial epiphysis required a re-surgery.

The following clinical observation can be as an example. Patient P., a 50-year-old woman, applied to the clinic with complaints of pain in the ankle joint, localized mostly on the outer side of the ankle joint.

She suffered a closed splintered intraarticular fracture of the right distal tibial epimetaphys a year and a half ago and received medical treatment. A surgery was performed: an open reduction, minimally invasive osteosynthesis of the ankle bones by an external fixation device. The postoperative period course was without problems. Over the time the patient began having pain localized mainly along the external part of the joint. Analysis of the radiographs at hospitalization revealed consolidation of the fracture, the malleolar angle was $10^{\circ}(\mathrm{m})$, the frontal epidiaphysis angle was $18^{\circ}(\mathrm{n})$. Surgery was performed, namely: corrective osteotomy of fibula and tibia of the right ankle, fixation with external fixation device. The course of the postoperative period was without problems. External fixation device was removed 4 months after the surgery. On the examination 12 months after the surgery there were no complaints. She walked without assistive devices using. The volume of motions was $0^{\circ} / 0^{\circ} / 35^{\circ}$ (Fig. 2). Radiological examination revealed that the joint cleft was retained, the frontal epidiaphysis angle was $2^{\circ}$ and the malleolar angle was $12^{\circ}$.

Patients with pseudarthrosis of the distal tibial epiphysis constitute a special group of patients. Treatment of distal tibial nonunion with bone loss is extremely difficult [6]. Prolonged joint inactivity as a result of pseudarthrosis leads to a rapid development of arthrosis changes and its further functioning impossibility. The main assistance to these patients aims at the limb weight-bearing capability restoration. Nowadays arthrodesis is reserved only for severe articular comminution which is otherwise nonreconstructable [7].

The following clinical observation can be an example. Patient P., a 79-year-old man, applied to the clinic with complaints about pain in the ankle joint and lower third of his ankle, deflection and absence of weight-bearing function of the right lower limb (Fig. 3).

Analysis of the X-rays at hospitalization revealed pseudarthrosis of the distal tibial epiphyseal cartilage and the lower third of the fibula malunion, malleolar angle was $10^{\circ}(\mathrm{m})$, the frontal epidiaphysis angle was with deviation to the $34^{\circ}(n)$, varus deformity was found. Surgery was performed: osteoplastic arthrodesis of the ankle joint with axial relationships correction and the pseudarthrosis reconstruction with a bone flap. Tightening screws were used for fixation. The course of the postoperative period ran without problems. Immobilization was carried out with a cylinder plaster cast for 3 months. Radiological examination revealed the preservation of axial relationships, the frontal epidiaphysis angle was $5^{\circ}$ and the bone flap remodeling.

Surgeons who are capable with techniques of internal fixation are best qualified to perform open reductions, while surgeons experienced with percutaneous fixation and hybrid external fixator application should use this method [9]. The principal aim is to avoid the ankle arthritis development, which often results in a serious functional impairment with 

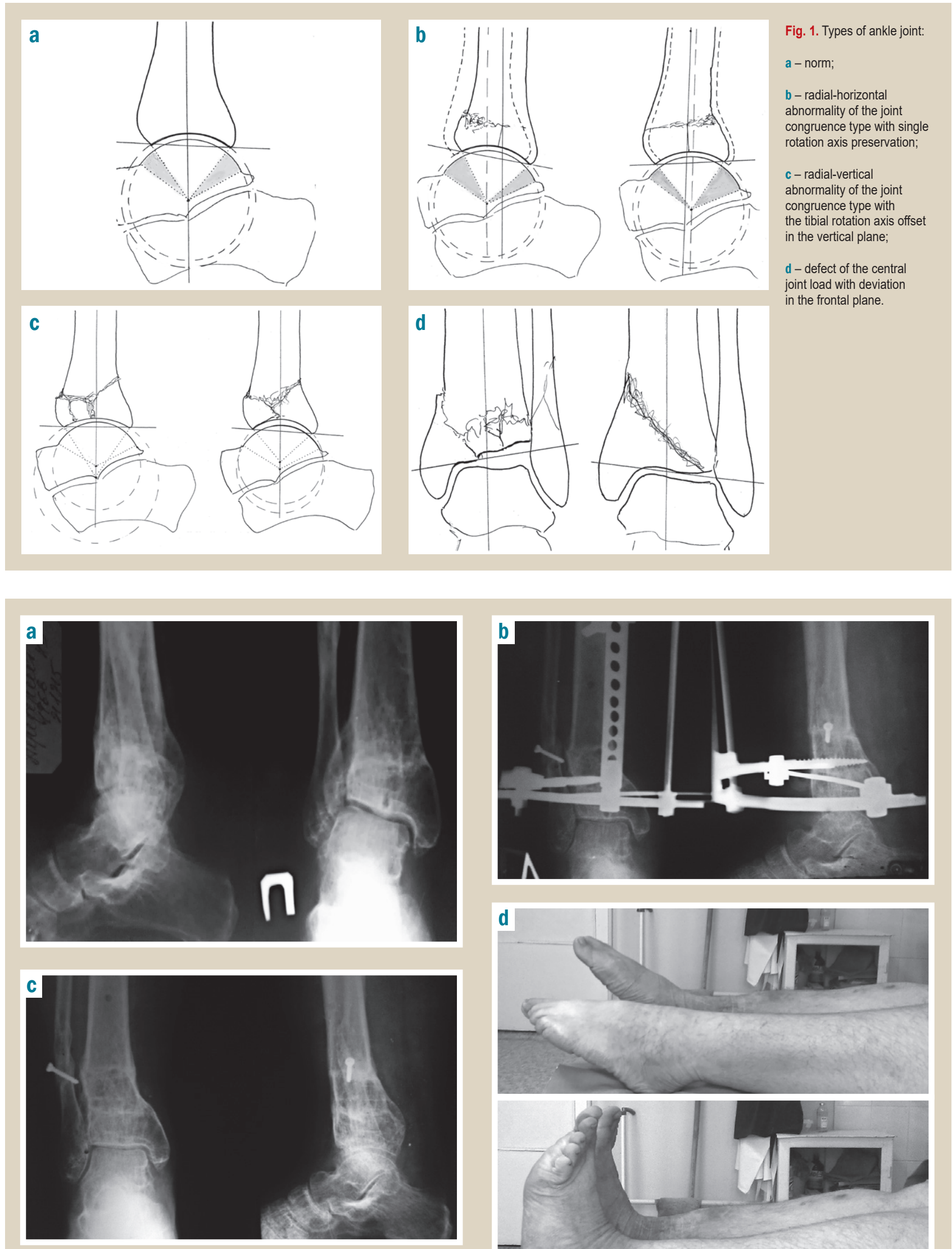

Fig. 2. Photographic prints of $X$-rays and the limb appearance of patient $P$., a 50-yearold woman, at the stages of treatment: $a$ - at hospitalization; $b-X$-rays at the time of external fixation device removal; $c$ - X-ray scans 12 months after surgery; $d$ - function of the ankle joint 12 months after surgery.

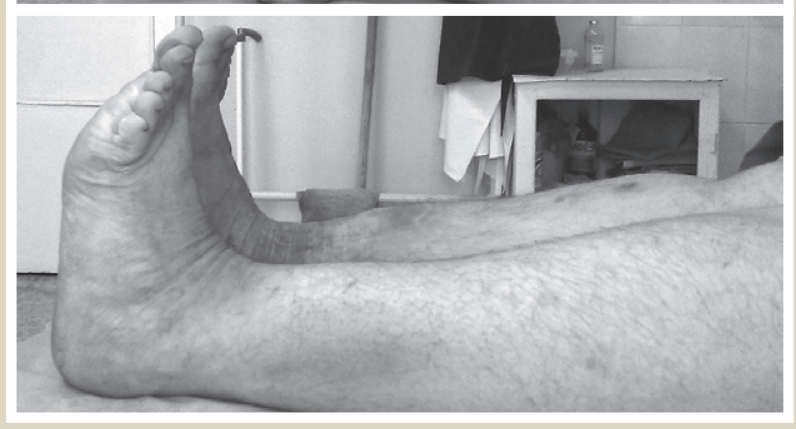



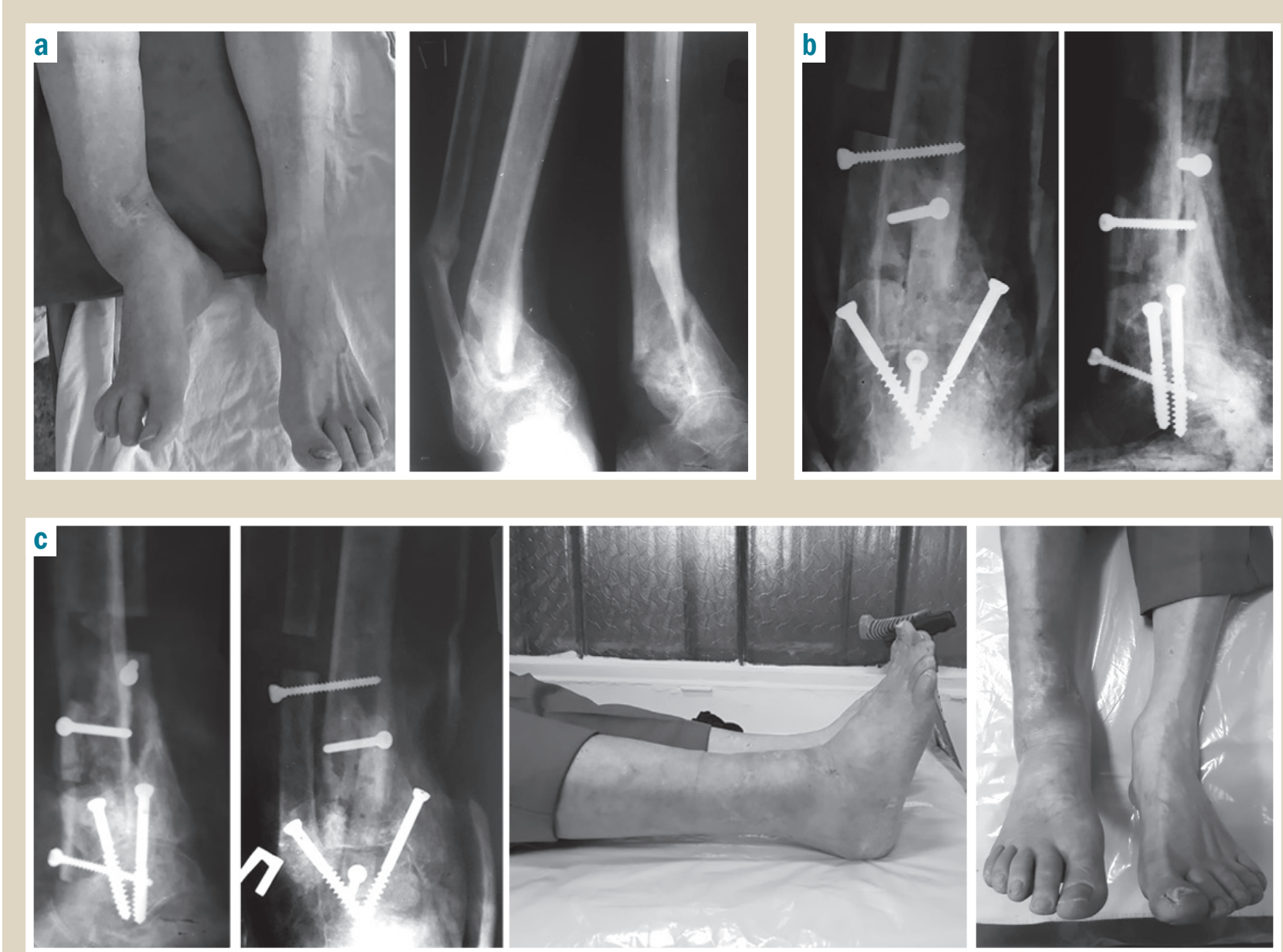

Fig. 3. Photographic prints of $\mathrm{X}$-rays and the limb appearance of patient $\mathrm{K}$., a 79-year-old man, at the stages of treatment: a - at hospitalization; b - X-rays after surgery; c - X-rays and the limb appearance 3 months later at the time of immobilization removal.

significant implications for employment following this type of the distal tibia posttraumatic deflection [10].

Therefore, it can be concluded that selective approach to surgical correction of posttraumatic deformations of the distal tibia is essential. The main indications for surgical correction are clear pseudarthrosis, deviations in the frontal plane of more than 10 degrees, pronounced joint arthrosis accompanied by pain syndrome for more than a year.

\section{Conclusions}

1. Patients who experienced a pilon fracture have the main pathological symptom such as the joint function limitation, which spreads to the extension sector, regardless of the fracture type. The pain syndrome in patients with a pilon fracture decreases over time, but the majority of patients do not have it at all after a year. The joint continues to function, but with a reduced amplitude of motions.

2. The main task of the distal tibial epiphysis surgical correction is the weight-bearing function and axial relationships restoration and pain management.

3. Clinically and biomechanically the most unfavorable type of discongruence is the articular surface of the distal tibial epimetaphys deflection in the frontal plane, which requires repeated surgical correction.
Prospects for further scientific research consist of studying the violation or disturbance of bone regeneration on the background of the limb axis changes which would give the possibility to determine the optimal method of surgical treatment and correction of the bone tissue mineral density by medications. To clearly identify the criteria of the limb axis permissible displacement degree for the ankle joint safe functioning with minimal degenerative changes in it.

Conflicts of Interest: authors have no conflict of interest to declare. Конфлікт інтересів: віАсутній.

\section{Information about authors:}

Trufanov I. I., MD, PhD, Assistant, Department of Orthopedics and Traumatology, State Institution "Zaporizhzhia Medical Academy of Post-Graduate Education Ministry of Health of Ukraine".

Pobiel Ye. A. , MD, PhD, DSc, Associate Professor, Head of the Department of Orthopedics and Traumatology, State Institution "Zaporizhzhia Medical Academy of Post-Graduate Education Ministry of Health of Ukraine".

Kosylo V. V., MD, Postgraduate, Department of Orthopedics and Traumatology, State Institution "Zaporizhzhia Medical Academy of Post-Graduate Education Ministry of Health of Ukraine". 
Відомості про авторів:

Труфанов І. І., канА. меА. наук, асистент каф. травматології

та ортопедії, АЗ «Запорізька медична академія післядипломної освіти МОЗ України".

Побєл Є. А. , А-р меА. наук, зав. каф. травматології та ортопедії, A3 «Запорізька медична академія післядипломної освіти МО3 України".

Косило В. В., киінічний орАинатор каф. травматології та ортопедії, АЗ «Запорізька меАична академія післядипломної освіти МОЗ Україним.

\section{Сведения об авторах:}

Труфанов И. И., канА. меА. наук, ассистент каф. травматологии и ортопеАии, ГУ «Запорожская медицинская акаАемия послеАипмомного образования МЗ Украины".

Побел Е. А. , А-р меА. наук, зав. каф. травматологии и ортопеАии, ГУ «Запорожская меАицинская акаАемия последипломного образования МЗ Украиным. Косило В. В., клинический орАинатор каф. травматологии и ортопеАии, ГУ “Запорожская меАицинская акаАемия последипломного образования МЗ Украины».

НаАійшла Ао редакції / Received: 02.10.2017

Після Аоопрацювання / Revised: 28.12.2017

Прийнято Ао Аруку / Accepted: 12.01.2018

\section{References}

[1] Slastinin, V. V., Klyukvin, I. Y., Filippov, O. P., \& Bogolyubsky, Y. A. (2015). Vnutrisustavnye perelomy distal'nogo otdela bol'shebercovoo kosti: e'volyuciya vzglyadov na khirurgicheskoe lechenie (obzor literatury) [Intra-articular fractures of the distal tibia: evolving of views on surgical treatment]. Zhurnal im. N.V. Sklifosofskogo. Neotlozhnaya medicinskaya pomoshch', 3, 23-29 [in Russian].

[2] Trufanov, I. I., \& Mirenkov, K. V. (2013). Vidy diskongruentnosti golenostopnogo sustava posle lecheniya perelomov PILON [The Types of Incongruence Ankle Joint Post Treatment of Pilon Fractures]. Litopys travmatolohii ta ortopedii, 1-2, 56-60. [in Russian].

[3] Korzh, N. A., Romanenko, K K., Goridova, L. D., \& Prozorovsky, D. V. (2011). Perelomy kostej goleni na urovne distal'nogo e'pimetafiza (perelomy pilon'a) i ikh posledstviya, diagnostika i lechenie [Fractures of Distal Epimetaphysis of Tibia (Pilon Fractures) and Their Consequences, Diagnostics and Treatment]. Travma, 12(2), 6-10. [in Russian].

[4] Tkachuk, N. A., Veretelnik, O. V., \& Trufanov, I. I. (2009). Matematicheskoe modelirovanie povedeniya biomekhanicheskoj sistemy pri nagruzhenii [Mathematical modeling of biomechanical system behavior under load]. Visnyk NTU "KhPl». Tematychnyi vypusk «Mashynoznavstvo ta SAPR», 28, 106-127. [in Russian].

[5] de Boer, P., \& Metcalfe, R. (2003) Pilon fractures of the tibia. Current Orthopaedics, 17(3), 190-199.

[6] Gulabi, D., Erdem, M., Cecen, G. S., Avci, C. C. Saglam, N., \& Saglam, F. (2014) llizarov Fixator Combined With an Intramedullary Nail for Tibial Nonunions With Bone Loss: Is It Effective? Clinical Orthopaedics and Related Research, 472(12), 3892-3901. doi: 10.1007/s11999014-3640-8.

[7] Hulscher, J. B., te Velde, E. A., Schuurman, A. H., Hoogendoorn, J. M., Kon, M., \& van der Werken, C. (2001) Arthrodesis after osteosynthesis and infection of the ankle joint. Injury, 32(2), 145-152. doi: 10.1016/ S0020-1383(00)00156-X.

[8] Mitkovic, M. B., Bumbasirevic, M. Z., Lesic, A., \& Golubovic, Z. (2002) Dynamic external fixation of comminuted intra-articular fractures of the distal tibia (type C pilon fractures). Acta Orthop Belg, 68(5), 508-514.

[9] Tomás-Hernández, J. (2016). High-energy pilon fractures management: State of the art. EFORT Open Reviews, 1(10), 354-361. doi: 10.1302/2058-5241.1.000016.

[10] Mayffrey, C., Vasario, G., Batiston, B., Lewis, C. Beazley, J., \& Selicson, D. (2011) Tibial pilon fractures: a review of incidence, diagnosis, treatment, and complication. Acta Orthoped. Belg., 77(4), 432-440. 